\title{
Exploration and Practice of Rigid Restraint System of Water Resources at County Level: A case study of Yongkang City
}

\author{
Suchun Chen ${ }^{1}$, Shiwu Wang ${ }^{2, *}$, and Jinxing $\mathrm{Li}^{2}$ \\ ${ }^{1}$ Yongkang Water Supply Management Centre. 321300 Yongkang, China. \\ ${ }^{2}$ Zhejiang Institute of Hydraulics and Estuary (Zhejiang Institute of Marine Planning and Design). 310020 Hangzhou, China.
}

\begin{abstract}
General Secretary Xi Jinping proposed to take water resources as the maximum rigid restriction, emphasize using water resources as its capacity permits, and actively explore new ways of high-quality development with regional characteristics. Yongkang is a water shortage county in the southern water-rich area. The contradiction between insufficient water supply and rapid economic and social development and continuous improvement of ecological environment is more prominent. In this paper, industrial water users are taken as the key control objects, and the added value of unit water consumption is taken as the rigid constraint index of water resources. It is incorporated into the reform of "heroes per acre" and integrated with the existing water resources management system to design the collaborative promotion mechanism framework of general rigid constraint of water resources. Then, the application practice in Yongkang is carried out, and the responsibilities of various administrative departments are clarified.
\end{abstract}

\section{Introduction}

Water, a basic natural resource and a strategic economic resource, is the source of life, the essential of production, and the foundation of ecology. All human activities are inseparable from water. In 2019, General Secretary Xi Jinping clarified that water resources should be as its capacity permits and the biggest rigid constraint to promote the transformation of water use from extensive and inefficient to intensive conservation at the Symposium on ecological protection and high-quality development of the Yellow River Basin ${ }^{[1]}$. Moreover, the sixth meeting of the Central Finance and Economics Committee in 2020 emphasized that the government should insist on using water resources as its capacity permits, resolutely curbing unreasonable water demand, and promoting the transformation of water use methods from extensive and inefficient to economical and intensive. Also, water-based cities, water-based land, water-based people, water-based production should be adhered to government management. Subsequently, the party and government made comprehensive arrangements for establishing and improving a rigid water resource constraint system ${ }^{[2]}$.

Due to the uneven distribution of precipitation during the year and between the years, the highly density population and economic ingredient, Yongkang is located in the southern water-rich area, but the per capita water resources are less than half of the national average. Shortage of water resources per capita caused some problems, such as seasonal water resources and water ecology damage, water environment pollution and etc. In recent years, Yongkang has improved the water resources management system and mechanism and water use efficiency through the most stringent water resources management system, construction of a water-saving society, and water-saving cities, but the contradiction between insufficient water supply and rapid economic and social development and continuous improvement of the ecological environment still exists. In order to alleviate the contradiction, and solve the regional water problems in an orderly manner, a general working mechanism framework of water resources rigid constraint, taking county as unit, is proposed in this study. Furthermore, practice of rigid restraint mechanism of water resources was carried out in Yongkang.

\section{Analysis on rigid restriction of water resources}

\subsection{The connotation and implementation status of water resources rigid constraint}

The rigid constraint of water resources cannot be mechanically understood as non-development. And insisting on ecological priority and protection priority is the essence. In order to promote high-quality social and economic development, strictly controlling water resources development, comprehensively improving water resources utilization efficiency, and promoting intensive and economical use of water resources must be carried out in accordance with the principles of waterbased city, water-based land, water-based people, and water-based production, on the basis of scientific accounting of the exploitable water resources. Wu Q et al. considered that the core is to force the transformation of

\footnotetext{
*Corresponding author: 743301322@qq.com
} 
economic and social development through the rigid restraint system of water resources, take the road of highquality development, eliminate water waste and water environmental pollution, and make the results of reform and development more and more equitable to all people ${ }^{[3]}$.

Currently, the implementation of the rigid restraint system of water resources is based on the current water resources management system. Since 2011, according to the Water Act, the central government and local governments have established the most stringent water resources management system, consisting of total amount control and quota management, three red lines and four systems, and formed a water resources management system with Chinese characteristics. This institutional system has played a huge role in promoting water resources conservation and protection, rational development and orderly utilization of water resources. Nevertheless, the current water resources management standard system, combining total quantity control and quota management, also has limitations.

First of all, the smallest measurement of total quantity control is county-level administrative regions. Due to the large number of water users in the county, macro-control indicators at regional scale cannot be implemented to the specific measurement objects, which makes it difficult to implement rigid constraints.

Secondly, the current quota management system approves water quotas based on individual products. Actually, dozens or even hundreds of products are produced by most individual water users, particularly in the industrial sector. Product quotas in various industries are not only numerous but also too micro. Moreover, internal product water use and reuse is the responsibility of enterprises, and it is difficult for the competent department of water conservancy industry to manage it. Consequently, over-quota progressive price increase system is difficult to implement by the government.

Thirdly, from the objective reality of water resources management, water intake indicators with water users as the measurement object is really useful, in accordance with the current effective laws and regulations. However, there are currently no measurement indicators for such objects. Therefore, the foundation of rigid restraint system of water resources is to improve the water quota for water users, that is, water consumption standards for water users.

\subsection{Analysis of key objects of rigid restraint of water resources}

According to the classification of water use objects, the main objects of water intake management outside rivers include domestic water, agricultural water, and industrial water. Domestic water occupies $14.5 \%$ of the total water, mainly for residents' basic domestic water. Ensuring that domestic water is the foundation of human rights to survival and development is an important part of $\mathrm{Xi}$ Jinping's people-centered thinking. Therefore, domestic water should not be the subject of rigid constraints. The focus of domestic water saving is to ensure reasonable water use and curb unreasonable water use. Everyone has the responsibility and obligation to save water.
Agricultural water consumption accounts for $61.2 \%$ of the total water consumption. Under the constraints of the red line of cultivated land, agricultural water consumption is not likely to increase (mainly refers to the southern water-rich areas). Meanwhile, agricultural water use involves food production, and food security is an important foundation of national security, so it is not practical to impose rigid constraints on agricultural water consumption. Industrial water accounts for $20.2 \%$ of total water consumption, accounting for a large proportion. On the one hand, some regions and some industrial sectors have extensive water use, and there is greater room for improvement in water efficiency; on the other hand, the water consumption growth caused by the rapid development of manufacturing-based industries and the resulting ecological and environmental problems caused by the increase of water consumption are prominent problems in current water resources management. Therefore, this paper takes industrial water as the rigid control object of water resources.

\section{The construction of rigid restraint system of water resources}

\subsection{General idea}

Since 2014, "Heroes per acre", as the starting point by Zhejiang Province to deepen the market-oriented reform of the allocation of resource elements, and strengthen the positive incentive and reverse force work mechanisms by focusing on linkage and strengthening coordination, is an important measure to force industrial enterprises to transform and upgrade, and promote the high-quality development of the industrial industry from point to surface $^{[4]}$.

For industrial water, this study explores the integration mechanism of the reform of "Heroes per acre" and rigid constraints on water resources to form a synergy of rigid constraints on water resources, further to promote the implementation of rigid constraints on water resources.

\subsection{Construction of collaborative promotion mechanism framework}

This study relies on the "Heroes per acre" reform being deepened by the People's Government of Zhejiang Province, and incorporates water consumption indicators into the integrative efficiency evaluation system of per acre of industrial enterprises, further to improve and optimize the comprehensive evaluation methods for per acre. For existing water users, those with high water efficiency will be given positive incentives; those with low water efficiency will be forced to remediate or transform. For new water users, the water consumption standard is used as the entry condition.

\subsubsection{The promotion mechanism of "Heroes per acre"}

For existing water users, from the perspective of the 
coordination of basic data for indicator calculations, water consumption indicators, referring to indicators such as energy consumption, emissions benefit, economy per acre, included in the comprehensive evaluation method of regional yield, should be selected by the water administrative department in conjunction with the economic and information department. The Per Acre Office is responsible for including it into the comprehensive evaluation index system of regional yield per acre.

Water consumption index weights are set by the Per Acre Office. The water administrative department is responsible for calculating the water consumption index evaluation scores of industrial enterprises based on the weights, economic data provided by the statistics department and the taxation department and the water consumption data within the water conservancy department. The Per Acre Office should be responsible for integrating the unit water consumption index evaluation score with other index evaluation results, and then sort the industrial enterprises by industry, and divide the industrial enterprises into four types of enterprises A, B, C, and D according to the ranking.

For the assessed A, B, C, and D enterprises, the development and reform, economic and information, water conservancy, environmental protection, housing construction and other departments, organized by the local people's government, implement differentiated allocation of resource elements such as land, electricity, gas, water, and credit funds according to their responsibilities. Also, it is applied in the aspects of enterprise evaluation, advanced recommendation, and enrolment of employees' children. Among them, positive incentives are carried out for category A enterprises, B and C enterprises are carried out to assist and upgrade, and category D enterprises are forced to rectify, thereby realizing the transformation of rigid water resource constraints from fuzzy control to precise control.

\subsubsection{Water consumption index determination mechanism}

For regional new water users, based on the current water consumption level of enterprises, the water administration department should decompose the total water consumption of regional water resources management and water efficiency control indicators to determine the water efficiency of the industry. Then, according to the economic development plan and priority guidance provided by the development and reform, economic and information departments, the standard value of water consumption indicators for various industries in the region is verified.

According to this standard value, departments such as the Ministry of Economics and Information, Technology and Natural Resources, should strictly manage the enterprise access during the process of entering the enterprise. If commitment to be at or ahead of water consumption access indicators, companies were allowed to enter; if not, companies not access.

\section{Practice of rigid restraint mechanism of water resources in industrial enterprises in Yongkang}

\subsection{Determination of water consumption index}

Existing water efficiency indicators include water consumption per acre, unit water consumption value added and etc. In consideration of easy accessibility and the synergy of existing indicators, unit water consumption value added is selected as the water consumption indicator, by analysing the characteristics of each indicator in table 1 and the evaluation indicators of the "Comprehensive Evaluation Method of per acre benefits of Industrial Enterprises in Yongkang City (Trial)" (Including tax revenue per acre, value added per acre, total labour productivity, unit energy consumption value added, unit emissions value added, research and development expenditures as a percentage of main business income, and sales revenue per acre $)^{[5]}$.

Table 1. Comparison and analysis table of current water efficiency

\begin{tabular}{|c|c|}
\hline $\begin{array}{l}\text { Indicator } \\
\text { name }\end{array}$ & Index characteristics \\
\hline $\begin{array}{c}\text { Water } \\
\text { consumption } \\
\text { per acre }\end{array}$ & $\begin{array}{c}\text { Comprehensive indicator: land area and } \\
\text { water consumption data are easy to obtain, } \\
\text { but this indictor is affected by industry type, } \\
\text { enterprise production load, production scale, } \\
\text { etc., and fail to characterize the direct } \\
\text { connection between water resources and } \\
\text { enterprise output. }\end{array}$ \\
\hline $\begin{array}{l}\text { Unit water } \\
\text { consumption } \\
\text { value added }\end{array}$ & $\begin{array}{l}\text { Comprehensive indicators. It can visually } \\
\text { characterize the relationship between the } \\
\text { consumption of water resources and } \\
\text { economic benefits, and the value-added and } \\
\text { water consumption data are easy to obtain, } \\
\text { and are not affected by the production scale } \\
\text { and load of the enterprise, but there is no } \\
\text { value-added data for the enterprise under the } \\
\text { regulations. }\end{array}$ \\
\hline $\begin{array}{c}\text { Water } \\
\text { consumption } \\
\text { per unit } \\
\text { product }\end{array}$ & $\begin{array}{l}\text { Single index. It is closely related to the types } \\
\text { of enterprise products and industries, but the } \\
\text { types are complex, the actual operability is } \\
\text { poor, and it fails to characterize the marginal } \\
\text { effect of water input and output. }\end{array}$ \\
\hline $\begin{array}{l}\text { Unit water } \\
\text { consumption } \\
\text { tax }\end{array}$ & $\begin{array}{l}\text { Comprehensive indicators. It can visually } \\
\text { characterize the relationship between the } \\
\text { consumption of water resources and } \\
\text { economic benefits, and the data is easy to } \\
\text { obtain, but the degree of intuition is inferior } \\
\text { to water consumption per unit of value } \\
\text { added, and is affected by the type of } \\
\text { industry. }\end{array}$ \\
\hline
\end{tabular}

\subsection{Determination of water consumption index value}

\subsubsection{Overview of BP neural network model}

According to the industrial structure of Yongkang City, the city can be divided into nine major industries: cup industry, 
automobile industry, power tool industry, electrical kitchenware industry, non-hardware industry, technical equipment industry, metal material industry, door industry and leisure appliances. Analysing the current situation of the city's nine major industries, the results of the unit water consumption value added of typical water users are shown in Figure 1 to Figure 9. With reference to the "Technical Guidelines for the Compilation of Water Quotas" (GB/T
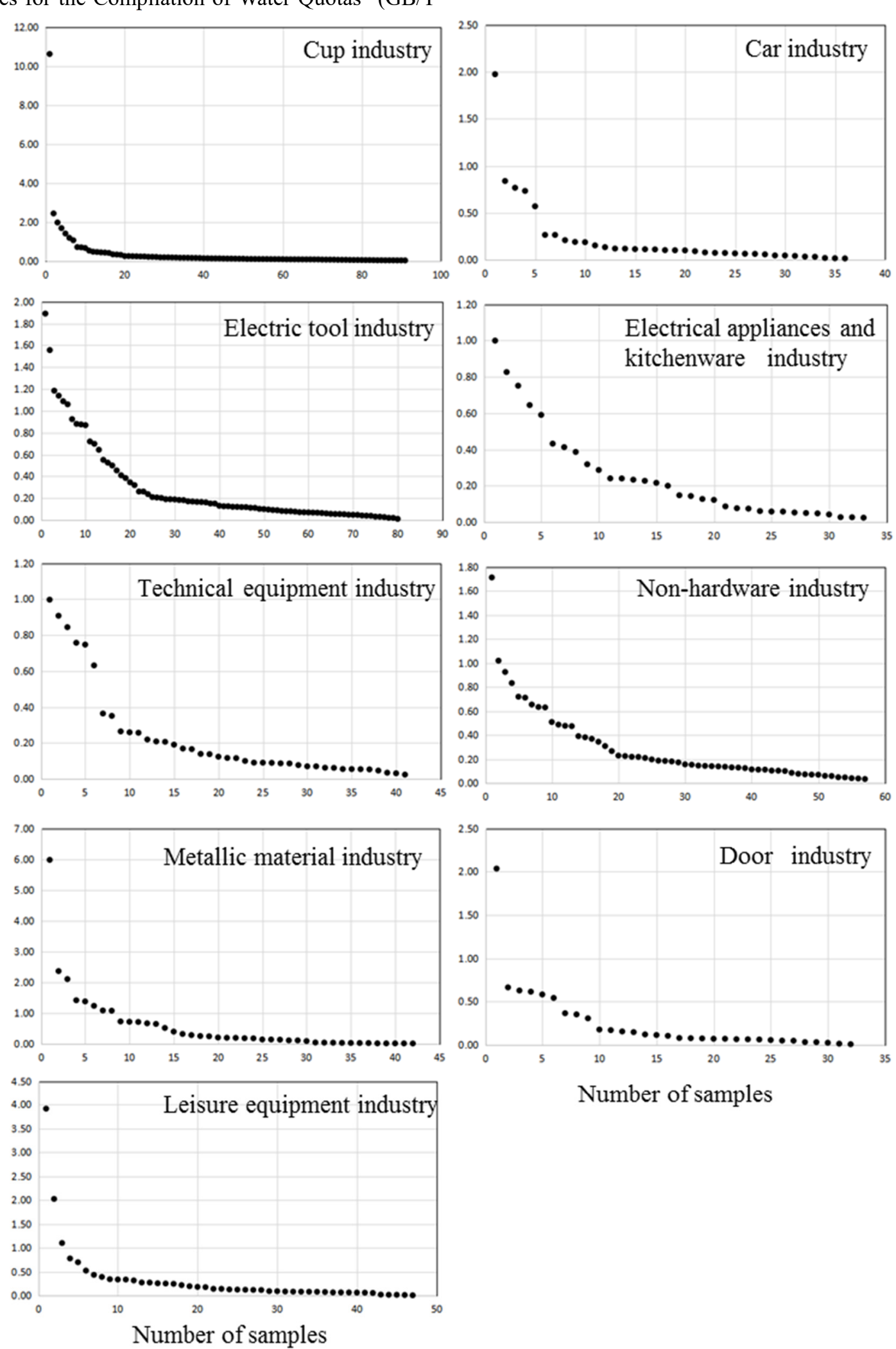

Number of samples

32716-2016) on the concepts of general and advanced quotas, the unit water consumption value added of typical water users in nine major industries is calculated in this paper, and the industry stock and new water consumption index values for water users are determined in accordance with the principles of $80 \%$ and $20 \%$ sample pass rates. The results are shown in table 2.
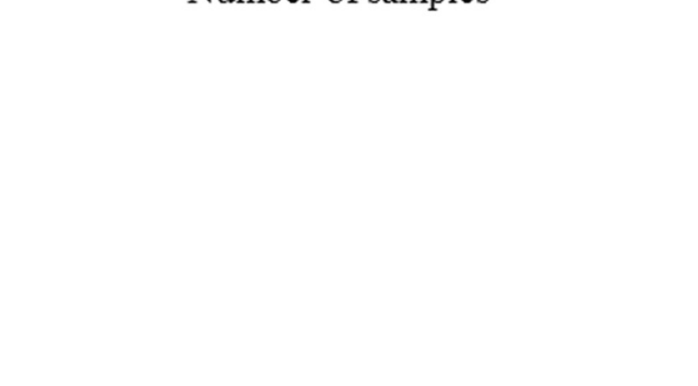

Fig. 1. Statistics of unit water consumption value added in nine major industries 
Table 2. Water consumption standard value table of the nine leading industries in Yongkang City

\begin{tabular}{|c|c|c|}
\hline \multirow{2}{*}{ Industry } & \multicolumn{2}{|c|}{$\begin{array}{c}\text { Unit water consumption } \\
\text { value added (ten thousand } \\
\mathbf{R M B} \mathbf{m}^{\mathbf{3}} \text { ) }\end{array}$} \\
\cline { 2 - 3 } & $\begin{array}{c}\text { Existing water } \\
\text { users }\end{array}$ & $\begin{array}{c}\text { New water } \\
\text { users }\end{array}$ \\
\hline Cup industry & 0.06 & 0.31 \\
\hline Car industry & 0.05 & 0.27 \\
\hline Electric tool industry & 0.06 & 0.50 \\
\hline $\begin{array}{c}\text { Electrical appliances and } \\
\text { kitchenware industry }\end{array}$ & 0.05 & 0.41 \\
\hline $\begin{array}{c}\text { Technical equipment } \\
\text { industry }\end{array}$ & 0.06 & 0.36 \\
\hline Non-hardware industry & 0.14 & 0.71 \\
\hline Metallic material & 0.03 & 0.72 \\
\hline Door industry & 0.05 & 0.54 \\
\hline Leisure equipment & 0.07 & 0.34 \\
\hline
\end{tabular}

\subsection{Water resources rigid restraint promotion mechanism}

The water consumption index, included into the comprehensive evaluation index system of per acre by Yongkang City's "Per Acre Office", occupies 5 points. Yongkang Water Affairs Bureau and Qianjiang Water Affairs Co., Ltd. are responsible for providing enterprise water consumption data, and the Municipal Statistics Bureau is responsible for verifying the data on enterprise industry classification and industrial value added. According to the data of water consumption and industrial value added, the Water Affairs Bureau verifies the actual water consumption value of industrial enterprises, and reports the scores of water consumption indicators for the "Per Acre Office" evaluation of enterprises in various industries. The "Per Acre Office" evaluates the comprehensive scores of each company's performance by integrating the scores of other indicators, and sorts by industry category. Then, companies in the nine major industries are divided into four categories: A, B, C, and D, and implement differentiated allocation of resource elements. Based on the evaluation results, Qianjiang Water Affairs Co., Ltd. is responsible for implementing differentiated water prices, and Yongkang Water Affairs Bureau is responsible for giving priority to A and B enterprises in terms of water intake permits and planned water consumption. Other departments are responsible for organizing and implementing differentiated allocation of resource elements according to their functions.

\subsection{Industrial enterprise access mechanism based on water consumption standards}

According to the water consumption access standards of the industrial sector approved by the Yongkang Water Affairs Bureau, in the process of organization and implementation in the introduction of enterprises and industry-related plans, the Municipal Bureau of Economy and Information Technology, the Municipal Bureau of Natural Resources and Planning, and the Administration of Industrial Parks should strictly manage the water consumption index for enterprises, and only allow industrial enterprises that meet or exceed the water consumption access index value to enter or expand production capacity.

\section{Conclusion}

There are some limitations in the current water resources management standard system combined with total water consumption control and quota management system. In this study, from the reality of regional water resources management, industrial water users are taken as the basic control objects, and the unit water consumption added value is selected as the water consumption index. Based on the existing water resources management system and unit water consumption added value, the rigid constraint of water resources and the reform practice of "heroes per acre" are integrated. Then, the universal cooperative promotion mechanism of acre average hero for the existing water users and the cooperative promotion mechanism of enterprise access for the new water users are designed. Furthermore, practice in Yongkang has effectively promoted the implementation of rigid constraints on water resources, alleviated the contradiction between supply and demand of regional water resources, and helped high-quality development.in addition, the formulation of water consumption standards and the coordination of administrative departments are the key links to establish a collaborative promotion mechanism for rigid constraints of water resources, which needs to be explored and studied in the future.

\section{Acknowledgements}

This study was supported by the National Key Research and Development Program of China (2019YFC0408800) and Science and Technology Plan Project of Zhejiang Water Resources Department (RC2036).

\section{References}

1. Xi J. (2019) Speech at Symposium on Ecological Protection and High Quality Development in the Yellow River Basin. China Water Resources, 20:1-3.

2. Department of water resources management, Ministry of water resources. (2020) The Important Role of Water Resources as the Maximum Rigid Constraint. China Water Resources, 5:1.

3. Wu Q, Ma Y, Li M. (2020) Deeply Understanding and Fully Implementing the Instructive Spirit of the General Secretary of the Internship ' Taking Water Resources as the Most Rigid Constraint '. Water Resources Development Research, 1:6.

4. Zhejiang Provincial People's Government. (2017) Guiding Opinions of the People 's Government of Zhejiang Province on Deepening the Reform of Heroes per Acre. Zhejiang Province. 
5. Yongkang Municipal People's government. (2019) Comprehensive Evaluation Method for Yield Benefit of Industrial Enterprises in Yongkang City. Yongkang City. 